\title{
Profil Penggunaan Antibiotik dan Peta Kuman pada Pasien Gangren Diabetes Melitus di Sebuah RSUD di Kabupaten Gresik
}

\author{
Isna Romadhona ${ }^{1,2}$, Fauna Herawati², Rika Yulia ${ }^{2}$ \\ ${ }^{1}$ RSUD Ibnu Sina, Gresik, Indonesia \\ 2Program Studi Magister Ilmu Farmasi Universitas Surabaya, Surabaya, Indonesia \\ Korespondensi: Fauna Herawati \\ Email:fauna@staff.ubaya.ac.id
}

Submitted : 25-08-2020, Revised : 28-08-2020, Accepted : 04-12-2020

\begin{abstract}
ABSTRAK: Antibiotik merupakan obat yang digunakan untuk mengatasi dan mencegah infeksi bakteri. Penggunaan antibiotik yang tidak tepat dapat menimbulkan berbagai masalah, diantaranya pengobatan akan lebih mahal dan juga risiko terjadinya resistensi bakteri terhadap antibiotik. Penelitian ini bertujuan untuk mengetahui profil penggunaan antibiotik dan profil peta kuman pada pasien gangren diabetes melitus di sebuah RSUD di Kabupaten Gresik serta untuk mengetahui kesesuaian penggunaan antibiotik dengan mengacu pada Permenkes Republik Indonesia No. 2406/Menkes/PER/XII/2011. Data penggunaan antibiotik diperoleh dari catatan Rekam Medis pada periode Januari - November 2017. Data penggunaan antibiotik dihitung dengan menggunakan rumus DDD/100 pasien-hari rawat. Hasil perhitungan DDD/100 pasien-hari rawat menunjukkan hasil sebesar 470,11 DDD/100 pasien-hari rawat. Peta kuman pada pasien gangren, melaporkan adanya bakteri Enterobacter cloacae 24\%, Escherichia coli 18\%, Staphylococcus aureus 15\%, Acinetobacter baumannii 9\%, Pseudomonas aeruginosa 6\%, Citrobacter youngae 6\%, Enterobacter aerogenes 6\%, Proteus vulgaris 6\%, Staphylococcus schleiferi 6\%, Klebsiella pneumoniae 3\%, dan Proteus mirabilis 3\%. Penggunaan antibiotik seftriakson dan metronidazol pada pasien gangren diabetes melitus di sebuah RSUD di Kabupaten Gresik pada periode Januari - November 2017 telah sesuai dengan pedoman penggunaan antibiotik berdasarkan Permenkes Republik Indonesia No. 2406/Menkes/PER/ XII/2011, yaitu antibiotik golongan sefalosporin generasi III yang lebih aktif terhadap Enterobacteriaceae dan antibiotik golongan nitroimidazol yang dapat mengobati infeksi bakteri basil anerob Gram-Negatif.
\end{abstract}

Kata kunci: antibiotik; gangren; diabetes melitus; DDD

\begin{abstract}
Antibiotics are drugs that are used to treat and prevent bacterial infections. Improper use of antibiotics can cause various problems, including treatment, which will be more expensive and also bacterial resistance to antibiotics. The purpose of this study was to determine the profile of antibiotic use and antibiotic susceptibility testing in patients with diabetes mellitus gangrene in a general hospital in Greaik district as well as to determine the suitability of antibiotic use concerning the Republic of Indonesia Minister of Health Regulation no. 2406/Menkes/PER/XII/2011. Data on antibiotic use was obtained from the Medical Record Installation from January to November 2017. The antibiotic use data was calculated using the DDD/100 patientday formula. The result of DDD/100 patient-day calculation shows a result of 470.11 DDD/100 patient-days. The results of the antibiotic susceptibility testing in patients with gangrene, including Enterobacter cloacae by $24 \%$, Escherichia coli by 18\%, Staphylococcus aureus by 15\%, Acinetobacter baumannii by $9 \%$, Pseudomonas aeruginosa by 6\%, Citrobacter youngae by 6\%, Enterobacter aerogenes by 6\%, Proteus vulgaris by 6\%, Staphylococcus schleiferi by 6\%, Klebsiella pneumoniae by 3\%, and Proteus mirabilis by 3\%. The use of antibiotics in patients with diabetes mellitus gangrene at a general hospital in Gresik district in the study period met guidelines on antibiotics used based on the Republic of Indonesia Minister of Health Regulation no. 2406/Menkes/PER/XII/2011, mostly generation III cephalosporins which are more active against Enterobacteriaceae and imidazole antibiotics which can cure Gram-Negative anerobic bacterial infection.
\end{abstract}

Keywords: antibiotics; gangrene; diabetes melitus; DDD 


\section{Pendahuluan}

Diabetes melitus merupakan penyakit kronis yang disebabkan oleh gagalnya organ pankreas dalam memproduksi insulin secara memadai sehingga menyebabkan peningkatan kadar glukosa dalam darah. Diabetes melitus memiliki resiko komplikasi dan mengancam jiwa jika tidak dikelola dengan baik [1,2]. Secara global, diabetes melitus merupakan salah satu dari 10 penyakit penyebab kematian [3]. Prevalensi diabetes melitus secara global pada tahun 2019 diperkirakan sebesar 463 juta orang naik menjadi 578 juta orang pada tahun 2030 dan 700 juta pada tahun 2045 [3]. Pada Tahun 2019 Indonesia menempati peringkat ke tujuh prevalensi diabetes melitus tertinggi di dunia setelah China, India, Amerika, Pakistan, Brazil, dan Meksiko dengan jumlah 10,7 juta orang di tahun 2019; diperkirakan 13,7 juta orang pada tahun 2030 dan 16,6 juta orang pada tahun 2045 [3].

Pasien diabetes melitus memiliki resiko sebesar 25\% mengalami komplikasi infeksi kaki diabetes yang disebabkan oleh bakteri. Infeksi pada kaki penderita diabetes melitus dapat berkembang menjadi gangren $[4,5]$. Pengobatan infeksi erat kaitannya dengan penggunaan antibiotik, terutama pada infeksi yang disebabkan oleh bakteri [6]. Infeksi dapat bertambah parah jika tidak dilakukan pengobatan antibiotik yang rasional, merujuk pada ketepatan dosis, pemilihan jenis antibiotik, dan bentuk sediaan yang diberikan kepada pasien [7]. Pemilihan antibiotik yang rasional (appropriate) diperlukan untuk mengurangi kegagalan terapi, resistensi bakteri terhadap antibiotik, risiko terjadinya efek samping, dan peningkatan biaya pengobatan $[6,8,9]$. Resistensi antibiotik yang dimaksud adalah kemampuan bakteri untuk bertahan hidup terhadap efek antibiotik sehingga tidak efektif dalam penggunaan klinis $[10,11]$. Pemilihan antibiotik yang rasional terdapat dalam pedoman terapi. Adanya pedoman terapi dan penggunaan antibiotik sesuai pedoman terapi serta pencegahan penyebaran infeksi akan meningkatkan luaran terapi antibiotik pada pasien diabetes gangren.

Hasil laporan tahun 2014 oleh Global Surveilance of Antibiotic Resistance yang dilakukan oleh World Health Organization (WHO) menunjukkan bahwa resistensi bakteri terhadap antibiotik merupakan ancaman bagi kesehatan masyarakat di seluruh dunia dan dapat menyebabkan penurunan efektivitas antibiotik yang kini terus berkembang hingga pada terapi antibiotik lini ketiga [12]. Berdasarkan hasil data yang dilakukan oleh Centers for Disease Control and Prevention (CDC) menunjukkan bahwa di Amerika Serikat, setiap tahun setidaknya 2 juta orang mengalami infeksi oleh bakteri yang resisten terhadap satu atau beberapa jenis antibiotik. Hal ini diperkuat 23.000 orang meninggal setiap tahunnya karena infeksi oleh bakteri yang telah resisten terhadap antibiotik [12].

Dalam upaya untuk mengontrol penyebaran bakteri yang resisten terhadap antibiotik, WHO dan CDC pada tahun 2014 merekomendasikan agar seluruh rumah sakit mengimplementasikan program antibiotic stewardship. Antibiotic stewardship merupakan kumpulan strategi koordinasi yang dilaksanakan untuk mendorong penggunaan antibiotik secara bijak melalui pemilihan golongan, dosis, dan durasi pengobatan antibiotik yang optimal sehingga dapat meningkatkan efektivitas antibiotik tanpa disertai dengan peningkatan efek samping maupun dampak yang berkelanjutan [13]. Di Indonesia seluruh rumah sakit kini sedang mempersiapkan strategi antibiotic stewardship melalui pembentukan tim Program Pengendalian Resistensi Antibiotik (PPRA) sesuai dengan Permenkes No. 8 tahun 2015 yang menyatakan bahwa setiap rumah sakit harus melaksanakan program pengendalian resistensi antimikroba secara optimal dan menggunakan pedoman umum penggunaan antibiotik sesuai dengan Permenkes No. 2406 tahun 2011 sebagai acuan penyusunan kebijakan penggunaan antibiotik di rumah sakit [14]. Sebuah RSUD di Kabupaten Gresik yang merupakan rumah sakit tipe B di Jawa Timur telah mempunyai PPRA dimana salah satu indikator mutu program pengenda- 
lian resistensi antimikroba di rumah sakit yaitu memberikan informasi penggunaan antibiotik di rumah sakit baik kuantitas maupun kualitas dapat tercapai. Namun, keberhasilan pelaksanaan program tersebut pada pasien diabetes gangren belum diteliti. Penelitian ini bertujuan untuk mengevaluasi penggunaan antibiotik yang digunakan oleh pasien diabetes gangren selama dirawat di rumah sakit.

\section{Bahan dan metode}

Penelitian ini merupakan penelitian observasional, analisis secara deskriptif yang dilakukan di sebuah RSUD di Kabupaten Gresik, Jawa Timur pada periode Januari - November 2017. Metode pengambilan data dilakukan dengan pendekatan retrospektif, yaitu dengan melakukan pengamatan terhadap data rekam medik, catatan penggunaan antibiotik instalasi farmasi, dan data hasil kultur pasien dengan infeksi gangren yang menjalani rawat inap di bangsal penyakit dalam. Analisis kesesuaian penggunaan antibiotik dan hasil kultur pasien dengan pedoman penggunaan antibiotik pada Permenkes Republik Indonesia No. 2406/Menkes/PER/XII/2011 serta penghitungan jumlah penggunaan antibiotik dengan satuan DDD/100 pasien-hari rawat.

\subsection{Kriteria inklusi dan eksklusi}

Sampel penggunaan antibiotik yang digunakan dalam penelitian ini adalah pasien dengan infeksi gangren yang mendapat terapi antibiotik dan menjalani rawat inap dengan kriteria inklusi dan kriteria eksklusi. Kriteria inklusi terdiri dari pasien usia dewasa ( $\geq 17$ tahun), dengan atau tanpa uji kultur kuman, dan dengan atau tanpa penyakit penyerta. Kriteria eksklusi terdiri dari pasien yang menjalani perawatan intensif, pasien dengan catatan rekam medis yang tidak terbaca atau tidak lengkap, dan pasien yang pulang paksa. Sampel peta kuman dalam penelitian ini dilakukan pada jumlah populasi yang menjalani pemeriksaan kultur.

\subsection{Teknik pengambilan sampel}

Teknik pengambilan sampel adalah total sampel (seluruh anggota populasi), yaitu dilakukan terhadap seluruh data pasien gangren diabetes melitus yang menjalani rawat inap di sebuah RSUD di Kabupaten Gresik pada periode Januari - November 2017.

\subsection{Pengambilan data}

Data yang digunakan bersumber dari rekam medis pasien, penjualan antibiotik di Instalasi Farmasi, dan data uji sensitivitas bakteri terhadap antibiotik dari hasil kultur. Tahap pertama untuk mengetahui profil penggunaan antibiotik dilakukan dengan mengumpulkan dan melakukan pencatatan terkait data-data yang diperlukan dari rekam medik pasien maupun catatan penggunaan obat serta mengklasifikasikan antibiotik yang didata melalui sistem klasifikasi ATC, kemudian dihitung kuantitas penggunaan antibiotik berdasarkan satuan Defined Daily Dose (DDD) yang selanjutnya diolah dan disajikan dalam bentuk tabel, grafik maupun gambar. Pada tahap kedua untuk menentukan profil peta kuman dilakukan dengan mencatat data kuman hasil kultur pasien, kemudian data diolah dan disajikan dalam bentuk tabel dan grafik.

\subsection{Perhitungan $D D D / 100$ hari rawat inap}

Perhitungan jumlah penggunaan antibiotik dengan satuan DDD per 100 pasien-hari rawat dilakukan untuk setiap antibiotik. Nilai DDD antibiotik ditentukan oleh WHO berdasarkan rata-rata dan indikasi utama pada orang dewasa. Tahapan perhitungan kuantitas penggunaan antibiotik adalah sebagai berikut:

a. Melakukan pencatatan semua data sesuai dengan kriteria

b. Melakukan perhitungan Total LOS (Length of Stay)

c. Melakukan perhitungan jumlah DDD antibiotik (gram)

DDD antibiotik $=\frac{\text { Jumlah dosis antibiotik selama dirawat (gram) }}{\text { DDD WHO antibiotik (gram) }}$ 
d. Menghitung DDD/100 pasien-hari rawat: DDD WHO (gram) sesuai dengan ATC/DDD, WHO 2020 (https://www.whocc.no/atc_ddd_ index/). Angka 100 untuk 100 hari rawat.

$$
\frac{D D D}{100} \text { hari rawat }=D D D \text { antibiotik } \times \frac{100}{\text { Total LOS }}
$$

\section{Hasil dan pembahasan}

Hasil dan pembahasan berfokus untuk menjawab tiga rumusan masalah dalam penelitian ini, yaitu (1) Untuk mengetahui profil penggunaan antibiotik berdasarkan metode perhitungan DDD/100 pasien-hari rawat pada penderita gangren di bangsal penyakit dalam di sebuah RSUD di Kabupaten Gresik pada periode Januari - November 2017; (2) Untuk mengetahui profil peta kuman pada penderita gangren di bangsal penyakit dalam di sebuah RSUD di Kabupaten Gresik; dan (3) Untuk mengetahui kesesuaian penggunaan antibiotik penderita gangren di bangsal di sebuah RSUD di Kabupaten Gresik dengan pedoman Permenkes Republik Indonesia No. 2406/Menkes/PER/XII/2011.

\subsection{Karakteristik demografi pasien}

Karakteristik dari 123 pasien berdasarkan jenis kelamin terbanyak adalah jenis kelamin perempuan sebanyak 69 pasien $(56,09 \%)$ sedangkan pasien dengan jenis kelamin lakilaki sebanyak 54 pasien $(43,91 \%)$. Berdasarkan usia, dikelompokkan menjadi 2, yaitu usia $<60$ tahun sebanyak 81 pasien $(65,85 \%)$ dan usia $\geq 60$ tahun sebanyak 42 pasien $(34,15 \%)$. Berdasarkan sumber pembiayaan, pasien dengan kepesertaan BPJS Kesehatan Non PBI (Penerima Bantuan Iuran) sebanyak 54,47\%. Jumlah pasien dengan kepesertaan BPJS Kesehatan PBI dalam periode Januari - November 2017 sejumlah 36 orang $(29,27 \%)$. Jumlah pasien diabetes gangren dengan kepesertaan BPJS Kesehatan PBI di sebuah RSUD di Kabupaten Gresik lebih sedikit daripada di Rumah Sakit Umum Daerah Sleman, yaitu 30 orang dalam periode 1 Januari 2014 sampai 10 Maret 2014 [15]. Berdasarkan riwayat penggunaan antibiotik, sebanyak 56 pasien $(45,53 \%)$ mendapat 2 jenis antibiotik dalam sehari (Tabel 1).

\subsection{Profil penggunaan antibiotik dinyatakan dalam DDD/100 hari rawat}

Berdasarkan hasil perhitungan DDD/100 pasien-hari rawat pasien selama periode Januari sampai dengan November 2017 menunjukkan total DDD/100 pasien-hari rawat sebesar 470,11 DDD/100 pasien-hari rawat (Tabel 2), dari penggunaan 16 kelompok antibiotik. Hasil perhitungan diperoleh dengan cara jumlah dosis yang diterima oleh pasien selama menjalani rawat inap dibagi dengan DDD yang ditetapkan oleh WHO berdasarkan jenis antibiotik. Hasil DDD yang diperoleh dibagi dengan total Length of Stay (LOS) dari 123 pasien lalu dikalikan 100. Hasil perhitungan DDD/100 pasien-hari rawat pada penelitian ini $(470,11$ DDD/100 pasienhari rawat) empat kali lebih tinggi daripada hasil penelitian DDD/100 pasien-hari rawat yang dilakukan di RS Samarinda Medika Citra pada pasien Ulkus Diabetik periode Januari sampai dengan Desember 2017 sebesar 52,86 DDD/100 pasien-hari rawat dengan jumlah sampel 59 pasien [16]. Pasien diabetes gangren di rumah sakit pada penelitian ini menggunakan beberapa macam antibiotik per hari dan antibiotik diberikan pada semua hari rawat (Tabel 1). Interpretasi $\mathrm{p}$ penggunaan antibiotik dengan satuan DDD/100 pasien-hari rawat haruslah dengan kritis karena dosis yang diresepkan sering tidak sesuai dengan dosis harian "biasa" (DDD yang ditetapkan oleh WHO), dosis antibiotik yang diresepkan tergantung pada lokasi infeksi, kerentanan organisme patogen, dan status metabolisme pasien [17].

Berdasarkan rute pemberian secara parenteral antibiotik yang memiliki perhitungan DDD/100 pasien-hari rawat paling besar, yaitu metronidazol infus sebesar 286,03 DDD/100 pasien-hari rawat (Tabel 2). Kuantitas penggunaan antibiotika yang dinyatakan dalam nilai DDD lebih tinggi dan tidak sesuai dengan nilai DDD WHO menandakan 
Tabel 1. Karakteristik demografi pasien

\begin{tabular}{llll}
\hline Karakteristik & & Jumlah (n=123 Pasien) & Persentase (\%) \\
\hline Jenis kelamin & Perempuan & 56 & 45,53 \\
& Laki-laki & 67 & 54,47 \\
Usia & $<60$ & 81 & 65,85 \\
& $\geq 60$ & 42 & 34,15 \\
Sumber Pembiayaan & Asuransi Mandiri & 2 & 1,63 \\
& Umum (Biaya Mandiri) & 18 & 14,63 \\
& BPJS PBI & 36 & 29,27 \\
& BPJS Non PBI & 67 & 54,47 \\
Penggunaan antibiotik selama dirawat & 1 & 11 & 8,94 \\
di rumah sakit (jenis) & 2 & 77 & 62,60 \\
& 3 & 28 & 22,76 \\
& 4 & 6 & 4,88 \\
& 5 & 1 & 0,81 \\
\hline Lama penggunaan antibiotik (hari) & $1-3$ & 75 & 60,97 \\
(n antibiotik = 285) & $4-6$ & 107 & 86,99 \\
& $\geq 7$ & 103 & 83,74 \\
\hline Lama rawat di rumah sakit (hari) & $2-3$ & 34 & 27,64 \\
& $4-5$ & 22 & 17,89 \\
& $6-7$ & 23 & 18,70 \\
& $\geq 8$ & 44 & 35,77 \\
\hline
\end{tabular}

bahwa peresepan dan penggunaan antibiotik pada pasien kemungkinan tidak selektif sehingga dikhawatirkan akan banyak ditemui peresepan dan penggunaan antibiotik yang tidak tepat indikasi sehingga hal ini akan berpengaruh pada kerasionalan penggunaan antibiotika dan kejadian bakteri resisten. Di Korea, penelitian Kwon menunjukkan bahwa karena kepekaannya terhadap bakteri Gram-Negatif menurun maka ampisilin/sulbaktam, amoksisilin/klavulanat, siprofloksasin dieksklusi dalam pemilihan terapi antibiotik definitif penyakit infeksi yang disebabkan oleh bakteri Gram-Negatif [6].

Pemberian terapi antibiotik pasien gangren di rumah sakit dimulai dengan pemberian parenteral dan dilanjutkan dengan terapi antibiotik oral apabila kondisi infeksi membaik [18]. Penggunaan terapi oral rifampisin dan klindamisin pada pasien rawat inap gangren diabetikum selama rawat inap dalam penelitian ini bertujuan sebagai antibiotik penunjang terapi, karena hasil laboratorium mikrobiologi klinik menunjukkan bahwa antibiotik tersebut sensitif (S) terhadap kuman yang ada pada luka gangren pasien.

\subsection{Profil peta kuman pada penderita gangren}

Dalam penelitian ini dilakukan tes kultur pada 54 pasien (44\%) dengan hasil positif pada 34 pasien dan hasil negatif pada 20 pasien. Hasil bakteri terbanyak adalah Enterobacter cloacae sebesar 24\% yang merupakan bakteri GramNegatif, diikuti berturut-turut Escherichia coli, Staphylococcus aureus, Acinetobacter baumannii, Pseudomonas aeruginosa, Citrobacter youngae, Enterobacter aerogenes, Proteus vulgaris, Staphylococcus schleiferi, Klebsiella pneumoniae, dan Proteus mirabilis masing-masing sebesar 


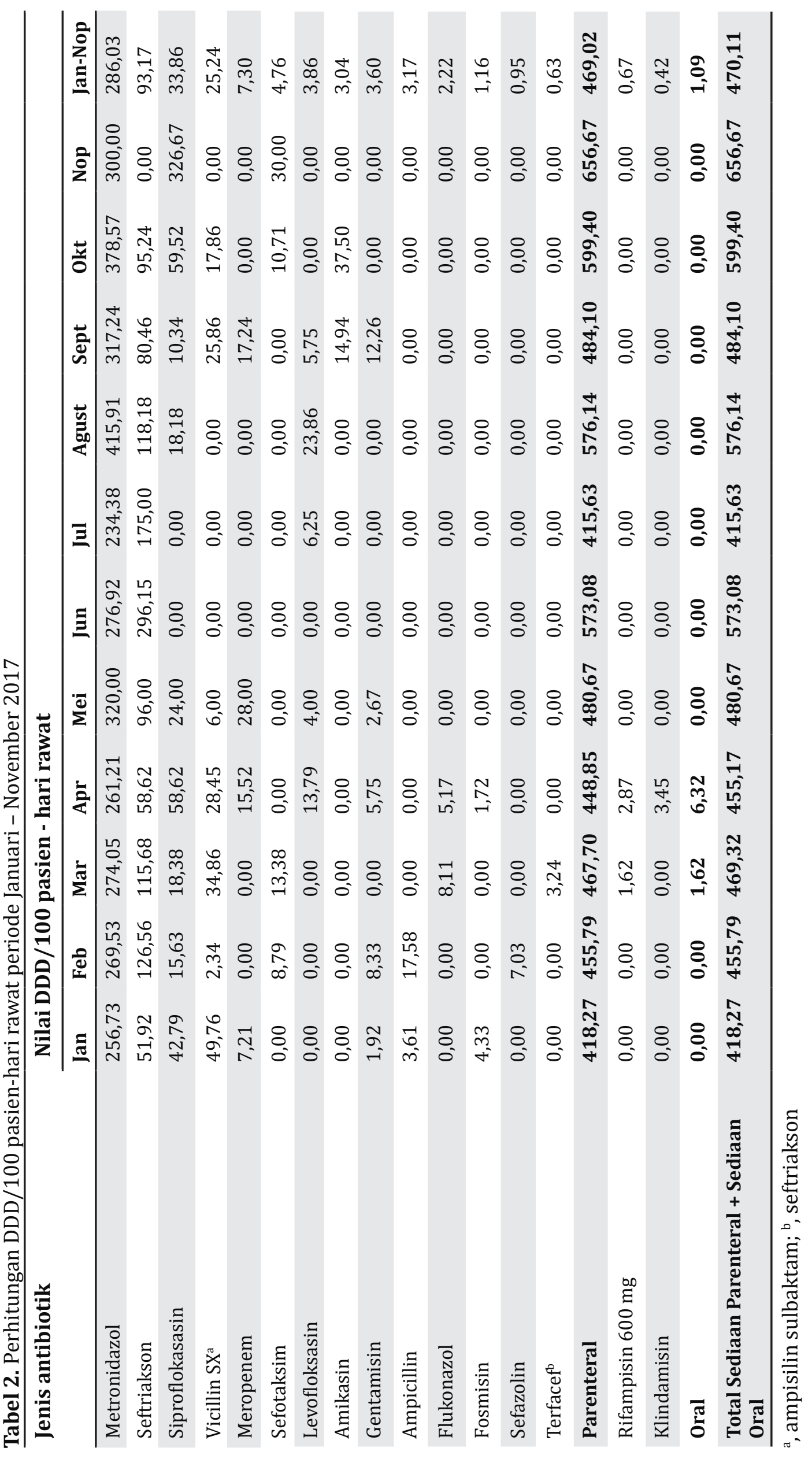


Tabel 3. Peta kuman pada penderita gangren

\begin{tabular}{lll}
\hline Nama bakteri & Frekuensi & Persentase (\%) \\
\hline Enterobacter cloacae & 8 & 24 \\
Escherichia coli & 6 & 18 \\
Staphylococcus aureus & 5 & 15 \\
Acinetobacter baumannii & 3 & 9 \\
Pseudomonas aeruginosa & 2 & 6 \\
Citrobacter youngae & 2 & 6 \\
Enterobacter aerogenes & 2 & 6 \\
Proteus vulgaris & 2 & 6 \\
Staphylococcus schleiferi & 2 & 6 \\
Klebsiella pneumonia & 1 & 3 \\
Proteus mirabilis & 1 & 3 \\
\hline
\end{tabular}

$18 \%, 15 \%, 9 \%, 6 \%, 6 \%, 6 \%, 6 \%, 3 \%$, dan $3 \%$. Profil peta kuman pada penderita gangren dapat dilihat pada Tabel 3. Hasil penelitian ini menunjukkan bahwa bakteri Gram-Negatif merupakan penyebab infeksi terbanyak. Hal ini berbeda dengan yang dilaporkan Putri, dkk. (2012) di RSAL di DKI Jakarta pada 18 pasien gangren diabetik yang melaporkan bahwa jenis bakteri dalam jumlah terbesar adalah bakteri Gram-Positif, yaitu Staphylococcus aureus 47,46\% [19]; sedangkan hasil observasi di RSI Surabaya Jemursari pada periode 2012-2016 menunjukkan bahwa bakteri Klebsiella pneumonia merupakan penyebab infeksi terbanyak (27\%) diantara kelima bakteri penyebab lain, yaitu Staphylococcus aureus (18\%), Staphylococcus non-haemolytic (18\%), Enterobacter aerogenes (18\%), Burkholderia cepacia (9\%), Escherichia coli (9\%) [20].

\subsection{Kesesuaian penggunaan antibiotik dengan Permenkes Republik Indonesia No. 2406/ Menkes/PER/XII/2011}

Hasil penelitian ini menunjukkan penggunaan antibiotik pada pasien diabetes gangren di sebuah RSUD di Kabupaten Gresik sudah sesuai dengan pedoman terapi penggunaan antibiotik, Permenkes No. 2406/Menkes/Per/ XII/2011, yaitu penggunaan seftriakson yang merupakan golongan sefalosporin generasi III memiliki aktivitas terhadap Enterobacteriaceae dan metronidazol merupakan antibiotik untuk mengobati penyakit infeksi yang disebabkan oleh bakteri basil anaerob Gram-Negatif [5].

\section{Keterbatasan penelitian}

Keterbatasan dalam penelitian ini adalah periode ijin penelitian berakhir pada bulan November 2017, oleh karena itu tidak dapat melaporkan penggunaan antibiotik pasien diabetes melitus dengan gangren yang menjalani rawat inap di sebuah RSUD di Kabupaten Gresik pada Desember 2017. Selain itu metode pendekatan retrospektif memiliki kelemahan terkait penulisan data rekam medik yang kurang lengkap.

\section{Kesimpulan}

Hasil penelitian menunjukkan bahwa secara kuantitatif penggunaan antibiotik yang paling banyak adalah metronidazol infus, yaitu sebesar 286,03 DDD/100 pasien-hari rawat. Hasil penelitian terkait peta kuman menunjukkan bahwa bakteri terbanyak pada pasien gangren diabetes melitus adalah Enterobacter clocae sebesar 24\% yang merupakan bakteri Gram-Negatif. Penggunaan antibiotik di sebuah RSUD di Kabupaten Gresik menunjukkan kesesuaian dengan pedoman penggunaan antibiotik berdasarkan Per- 
menkes Republik Indonesia No. 2406/Menkes/ PER/XII/2011.

\section{Ucapan Terima Kasih}

Penulis berterima kasih kepada direksi dan semua staf rekam medik di sebuah RSUD di Kabupaten Gresik.

\section{Daftar Pustaka}

1. Wu Y, Ding Y, Tanaka Y, Zhang W. Risk factors contributing to type 2 diabetes and recent advances in the treatment and prevention. Int J Med Sci. 2014;11(11):1185-200.

2. Nickerson HD, Dutta S. Diabetic complications: current challenges and opportunities.JCardiovasc Transl Res. 2012;5(4):375-9.

3. Yuen L, Saeedi P, Riaz M, Karuranga S, Divakar H, Levitt N, Yang X, Simmons D. Projections of the prevalence of hyperglycaemia in pregnancy in 2019 and beyond: Results from the International Diabetes Federation Diabetes Atlas, 9th edition. Diabetes Res Clin Pract. 2019;157:107841.

4. Diabetic Foot. Guidance on the diagnosis and management of foot infections in persons with diabetic. 2015.

5. Casqueiro J, Casqueiro J, Alves C. Infections in patients with diabetes mellitus: A review of pathogenesis. Indian J Endocrinol Metab. 2012;16(Suppl1):S27-S36.

6. Kwon KT, Armstrong DG. Microbiology and antimicrobial therapy for diabetic foot infections. Infect Chemother. 2018;50(1):11-20.

7. Leekha S, Terrell CL, Edson RS. General principles of antimicrobial therapy. Mayo Clin Proc. 2011;86(2):156-67.

8. Llor C, Bjerrum L. Antimicrobial resistance: risk associated with antibiotic overuse and initiatives to reduce the problem. Ther Adv Drug Saf. 2014;5(6):229-41.

9. Lázaro Martínez JL, García Álvarez Y, TardáguilaGarcía A, García Morales E. Optimal management of diabetic foot osteomyelitis: challenges and solutions. Diabetes Metab Syndr Obes. 2019;12:947-59

10. Gunawan GS. Farmakologi dan Terapi. 5th ed. Jakarta: Departemen Farmakologi dan Terapeutik FKUI. 2015.

11. Goodman LS, Brunton LL, Chabner B, Knollmann BC. (2011). Goodman \& Gilman's the pharmacological basis of therapeutics (12th ed.). New York: McGraw-Hill, Health Professions Division.

12. CDDEP. State of the World's Antibiotics. Washington, D.C: s.n. 2015.

13. CDC. Antibiotic / Antimicrobial Resistance. s.l.: CDC. Cent Dis Control Prev. 2016.

14. Peraturan Menteri Kesehatan Republik Indonesia Nomor 2406 tentang Pedoman umum penggunaan antibiotik. Jakarta: Departemen Kesehatan Republik Indonesia. 2011.

15. Widuri W, Sari DA, Faisal A. Hubungan kepatuhan prosedur tetap perawatan ulkus diabetikum dengan kepuasan pasien diabetes melitus pengguna BPJS PBI di RSUD Sleman. Journal of Health. 2016;3(1):19-23.

16. Wahyudi EA, Fadraersada F, Masruhim AM. Evaluasi Pengunaan Antibiotik berdasarkan metode DDD pada pasien Ulkus Diabetikum di RS Samarinda Medika Citra. Proceeding of the 8th Mulawarman Pharmaceuticals Conferences 2018.

17. Bansal D, Mangla S, Undela K, Gudala K, D'Cruz. S, Sachdev A, Tiwari P. Measurement of adult antimicrobial drug use in tertiary care hospital using defined daily dose and days of therapy. Indian J Pharm Sci. 2014;76(3):211-7.

18. Fincke BG, Miller DR, Christiansen CL, et al. Variation in antibiotic treatment for diabetic patients with serious foot infections: A retrospective observational study. BMC Health Serv Res. 2010;1(1):193.

19. Putri CS, Radji M, Fauziyah S. Kerasionalan penggunaan antibiotik pada pasien gangren kaki diabetes. RSAL Mintohardjo. 2012.

20. Donastin A, Aisyah A. Microbial pattern of diabetic foot ulcer patient in Jemursari Islamic Hospital Surabaya period 2012-2016. Indonesian 
Journal of Medical Laboratory Science and Technology.2019;1(1):22-32. 


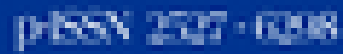

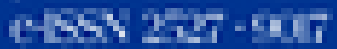
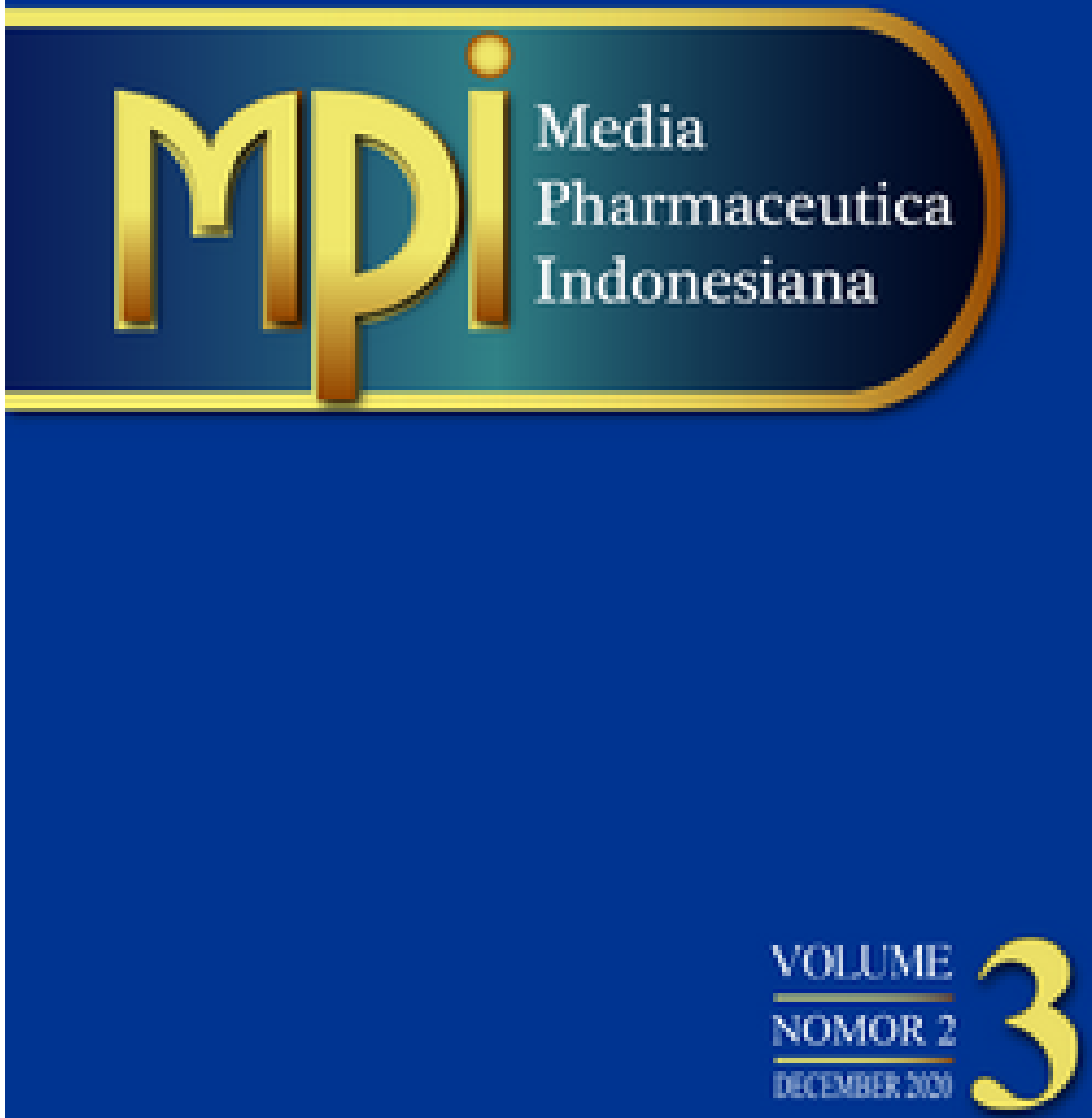
Journal Profile

MPI (Media Pharmaceutica Indonesiana)

eISSN : 25279017 I pISSN : 25276298

Health Science

Universitas Surabaya

\section{Cisinta}

S4

Sinta Score

\section{( $)$ Garuda}

Indexed by GARUDA

6

H-Index

6

H5-Index 
HAd rh th

chathit
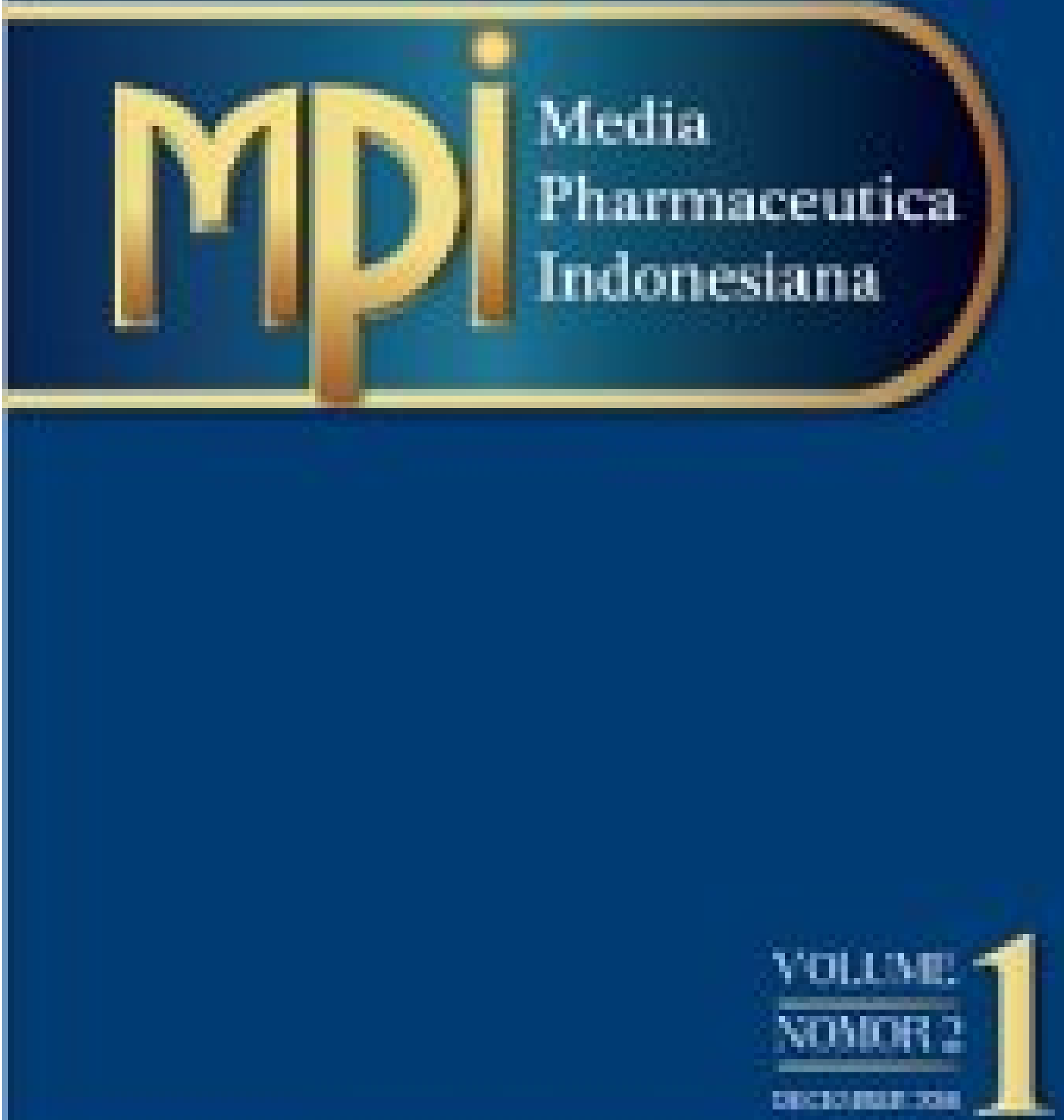
Address:

Faculty of Pharmacy FF Building, 6th floor, University of Surabaya Jl. Raya Kalirungkut, Surabaya 60293, Indonesia Surabaya

Email:

mpi@,unit.ubaya.ac.id

Phone:

Last Updated :

2021-06-15

2019

Q

Search..

Q

$$
\begin{array}{llll|l|l|l|l|l|l|}
\mathbf{1} & \ll & 1 & 2 & 3 & 4 & 5 & \text { Y }
\end{array}
$$

Page 1 of 8 / Total Records : 73

\section{Publications}

Citation

Sirih merah (Piper crocatum Ruiz \& Pav.) kajian pustaka aspek botani, kandungan kimia, dan aktivitas

farmakolog!

N Parfati, T Windono

Media Pharinaceutica Indonesiana 1 (2), 106-115, 2016

Uji Aktivitas Antioksidan Ekstrak Etanol Kayu Secang_(Caesalpinia sappan) Menggunakan Metode DPPH, $\underline{\text { ABTS}}$, dan FRAP

F Setiawan, O Yunita, A Kurniawan

Media Pharmaceutica Indonesiana 2 (2), 82-89, 2018

Pengembangan Model Hewan Coba Tikus Diabetes Mellitus Tipe 2 dengan Induksi Diet Tinggi Fruktosa Intragastrik

DD Wulansari, DD Wulandari

Media Pharmaceutica Indonesiana 2 (1), 41-47, 2018

Hubungan Persepsi Penyakit (Illness Perception) dengan Kontrol Gejala Asma pada Pasien Rawat Jalan A Lorensia, R Yulia, IS Wahyuningtyas

MPI (Media Pharmaceutica Indonesiana) 1 (2), 92-99, 2016 
A Yuniarto, N Selifiana

MPI (Media Pharmaceutica Indonesiana) 2 (1), 22-25, 2018

Aplikasi zebrafish (Danio rerio)_pada beberapa model penyakit eksperimental

A Yuniarto, EY Sukandar, I Fidrianny, IK Adnyana

MPI (Media Pharmaceutica Indonesiana) 1 (3), 116-126, 2017

Efek Pajanan Debu Kayu terhadap Gangguan Faal Paru

I Ma'rufi

MPI (Media Pharmaceutica Indonesiana) 1 (1), 45-52, 2016

Formulasi Sediaan Sabun Cuci Tangan Ekstrak Jeruk Nipis (Citrus aurantifolia) dan Efektivitasnya sebagai

Antiseptik

NIE Jayani, K Kartini, N Basirah

MPI (Media Pharmaceutica Indonesiana) 1 (4), 222-229, 2017

Pengembangan Formula dan Uji Stabilitas Fisik-pH Sediaan Gel Facial Wash yang Mengandung Ekstrak Etanol

Kulit Kayu Kesambi

G Eugresya, C Avanti, SA Uly

Media Pharmaceutica Indonesiana 1 (4), 181-188, 2017

Efektivitas Gel Kuersetin pada Penyembuhan Luka Bakar Derajat IIA

T Sutrisno, N Huda, N Nurlely, N Cahaya, VM Srikartika

MPI (Media Pharmaceutica Indonesiana) 1 (1), 1-11, 2016

Page 1 of 8 | Total Records : 73

$$
\begin{array}{llll|l|l|l|l|l|l|}
\hline \mathbf{K} & \ll & 1 & 2 & 3 & 4 & 5 & \Downarrow & \text { И }
\end{array}
$$

\section{Citation Statistics}
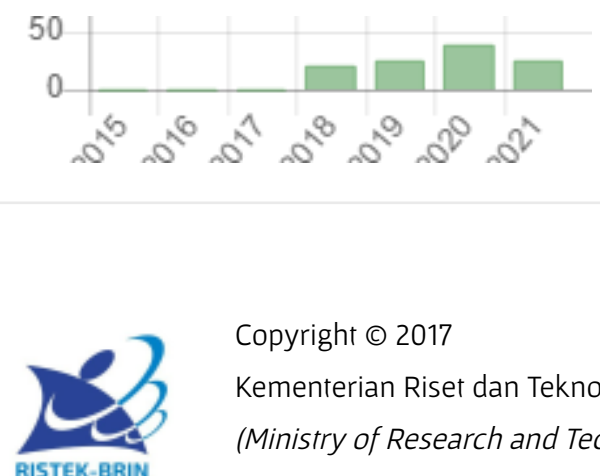

Copyright (c) 2017

Kementerian Riset dan Teknologi / Badan Riset dan Inovasi Nasional

(Ministry of Research and Technology /National Agency for Research and Innovation)

All Rights Reserved. 


\section{Editor in Chief}

Kartini, S.Si., M.Si., Apt., Ph.D. Sinta Scopus

\section{Associate Editor}

Dr. Herman J. Woerdenbag Scopus

Assoc. Prof. Dr. Omboon Vallisuta Scopus

Dr. Menino Osbert Cotta Scopus

Dr. Christina Avanti M.Si., Apt. Sinta Scopus

Prof. Dr. Dwi Setyawan, S.Si., M.Si., Apt. Sinta Scopus

Dr. Rika Yulia, S.Si., SpFRS., Apt. Sinta Scopus

Dr. Oeke Yunita, S.Si., M.Si., Apt. Sinta Scopus

Rr. Retno Widyowati, S.Si., M.Pharm., Apt. Sinta Scopus

Dr. Finna Setiawan, S.Farm., M.Si. Sinta Scopus

Desak Ketut Ernawati, S.Si., Apt., M.Pharm., Ph.D. Sinta Scopus

Dr. Susi Ari Kristina, M.Kes., Apt. Sinta Scopus

Dr. Dini Kesuma, S.Si., M.Si., Apt. Sinta Scopus

Hendri Wasito, S.Si., M.Sc., Apt Sinta Scopus

Prof. I Ketut Adnyana, M.Si., Ph.D. Sinta Scopus

\section{Administrator}

Siti Kusnul Khotimah

Maya Harfia A., A.Md. 


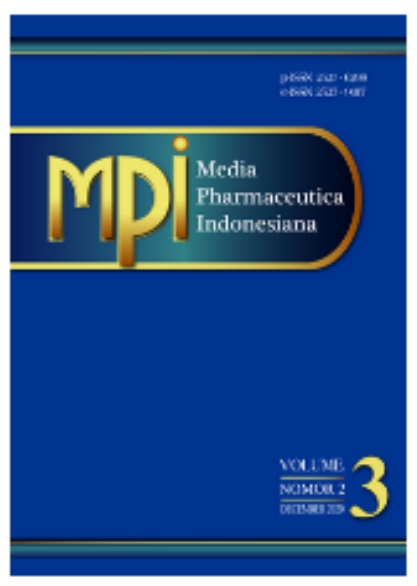

DOI: https://doi.org/10.24123/mpi.v3i2

PUBLISHED: 2020-12-22

\section{ORIGINAL RESEARCH ARTICLES}

Isolasi dan Uji Aktivitas Kitosan Cangkang Kerang Bulu (Anadara inflata) sebagai Antibakteri terhadap Staphylococcus epidermidis dan Escherichia coli

Suherman Baharuddin, Dewi Isnaeni

Abstract views: 0 PDF Downloads: 0 đ DOI: https://doi.org/10.24123/mpi.v3i2.3181

\section{PDF}

Evaluasi Pertumbuhan Suspensi Sel Dendrobium anosmum var. gigantea dan Aktivitasnya sebagai Antioksidan

Yanuar Prasetyo, Kristian Njudang, Handriyanto Mulyono Putra Wibowo, Alfian Hendra Krisnawan

Abstract views: 0 PDF Downloads: 0 क DOI: https://doi.org/10.24123/mpi.v3i2.2976

\section{PDF}

Pengaruh Pemberian Madu dari Lebah Apis mellifera, Apis cerana, dan Trigona sp. terhadap Beberapa Parameter Biokimia pada Mencit yang Diuji dengan Metode WFST

Mukti Priastomo, I Ketut Adnyana, Sukrasno Sukrasno, Kusnaedi Kusnaedi

All Abstract views: 0 PDF Downloads: 0 DOI: https://doi.org/10.24123/mpi.v3i2.3042

\section{PDF}

Analisis Kualitatif Penggunaan Antibiotik pada Pasien Rujukan dengan Metode Analisis Alur Gyssen di RSPAL Dr. Ramelan Surabaya

Ayu Maharani Ibrahim, Widyati Widyati, Frans O.H. Prasetyadi

All Abstract views: 0 PDF Downloads: 0 क DOI: https://doi.org/10.24123/mpi.v3i2.2567

\section{PDF}


Profil Penggunaan Antibiotik dan Peta Kuman pada Pasien Gangren Diabetes Melitus di Sebuah RSUD di Kabupaten Gresik

Isna Romadhona, Fauna Herawati, Rika Yulia

11 Abstract views: 0 PDF Downloads: 0 e DOI: https://doi.org/10.24123/mpi.v3i2.2966

\section{[ PDF}

Pengaruh Edukasi Perubahan Gaya Hidup Sehat terhadap Clinical Outcome pada Pasien di Rumah Diabetes Universitas Surabaya

Retna Eka Dewi, Sulistyo Emantoko Dwi Putra, Lisa Aditama, Heru Wijono

All Abstract views: 0 PDF Downloads: 0 e DOI: https://doi.org/10.24123/mpi.v3i2.2982

\section{圆 PDF}

\section{CRITICAL REVIEW}

Metode Monocyte Activation Test (MAT) dan Recombinant Factor C (rFC) sebagai Alternatif Metode Pengujian Pirogen bagi Perusahaan Farmasi di Indonesia

Andrea Santosa, Ida Bagus Made Artadana, Mariana Wahjudi

1 Abstract views: 0 the PDF Downloads: 0 d DOI: https://doi.org/10.24123/mpi.v3i2.2987

[D PDF 